\title{
Fører streng alkoholpolitikk til mindre sykdom?
}

\author{
Er det sammenheng mellom folkehelsepolitikk, alkoholkonsum og hjerte- \\ sykdom? En studie fra Texas tyder på det.
}

Sammenhengen mellom alkohol og hjertesykdom er blitt undersøkt i en rekke tidligere studier, men én svakhet ved disse har vært at de har vært basert på selvrapportert alkoholinntak. Da kan det være vanskelig å kontrollere for konfunderende faktorer.

I en ny studie som nylig er publisert i tidsskriftet $B M J$, ble over 1,1 million pasienter i staten Texas i USA fulgt $\mathrm{i}$ over fem år fra 2005 (1). Pasientene ble klassifisert i to grupper ut fra bosted - fylker (counties) med liberal alkoholpolitikk og fylker med streng politikk. I områder med liberal alkoholpolitikk var det økt forekomst (oddsratio 1,05; $95 \%$ KI 1,01-1,09) og insidens (hasardratio 1,07; $95 \% \mathrm{KI} 1,01-1,13)$ av atrieflimmer, lavere

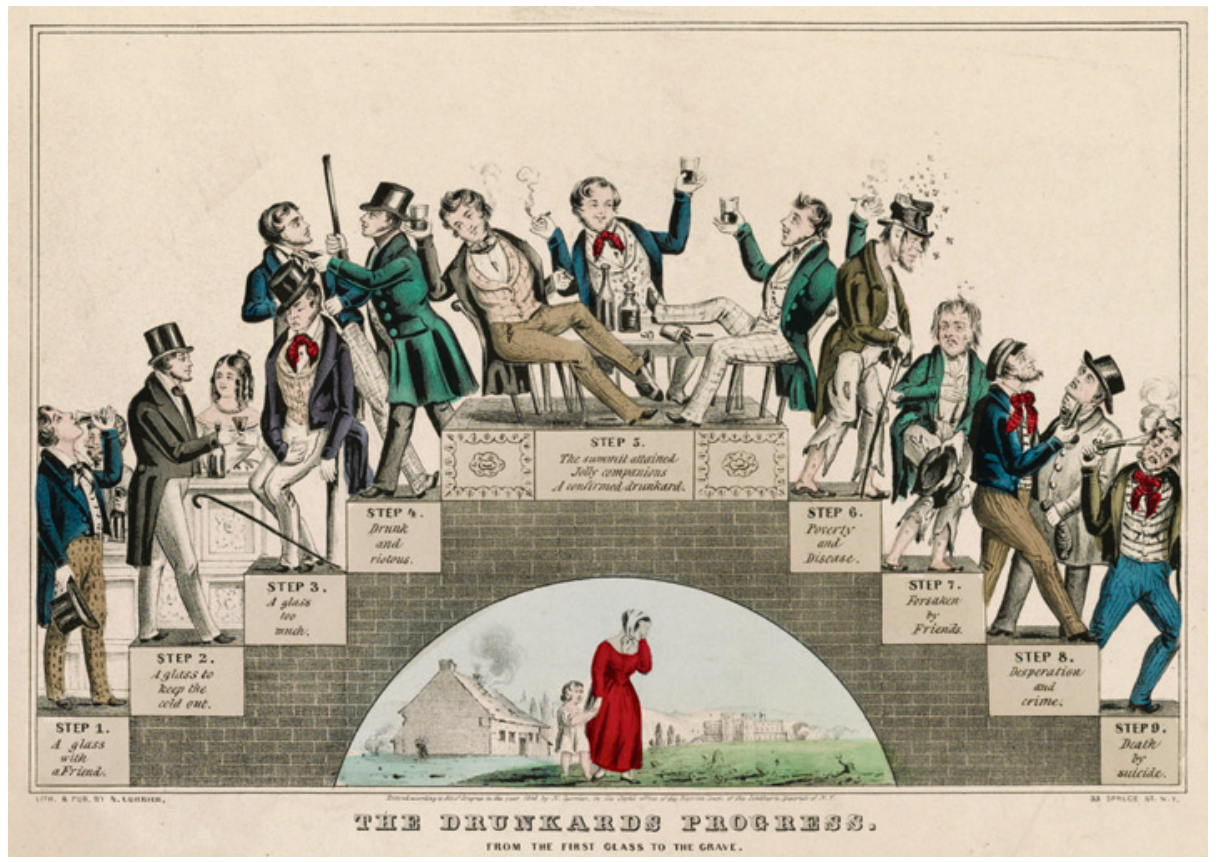

The Drunkard's Progress. From the first glass to the grave. Litografi fra 1846. Wikimedia Commons

prevalens (OR 0,83; $95 \%$ KI $0,79-0,87)$ og insidens (HR 0,91; $95 \%$ KI 0,87-0,99) av hjerteinfarkt og lavere prevalens (OR 0,87; $95 \%$ KI 0,84-0,90) av hjertesvikt. I områder som gjennomgikk lovskifte fra streng til liberal politikk i observasjonstiden, var det høyere insidens av alkoholmisbruk, alkoholisk leversykdom, atrieflimmer og hjertesvikt, men ingen forskjell i hjerteinfarkt.

- Denne studien er viktig fordi den utfyller kunnskapsgrunnlaget om årsakssammenhengen mellom alkoholforbruk og hjerte- og karsykdommer, sier Øyvind Næss, som er lege og forsker ved Folkehelseinstituttet og Universitetet i Oslo. - Man studerer en intervensjon som er relevant $i$ denne sammenheng, nemlig lovregulering, sier han. Studien gir indikasjoner på økt forekomst av alkoholmisbruk og leverskader i områder der lovgivningen blir liberalisert.

- Studien passer inn i en ny trend hvor man ønsker å bruke såkalt naturlige eksperimenter på områder hvor det er vanskelig å gjøre randomiserte forsøk og der det fortsatt er usikkerhet ut fra observasjonsstudier, sier Næss, som understreker at forholdene i Texas er svært annerledes enn i Norge. - Det mest relevante for Norge er kanskje hva som kan skje med sykdomsforekomsten i populasjoner der lovgivningen blir liberalisert raskt, sier han.

\section{Ketil Slagstad \\ Tidsskriftet}

\section{Litteratur}

1. Dukes JW. Dewland TA, Vittinghoff $E$ et al. Access to alcohol and heart disease among patients in hospital: observational cohort study using differences in alcohol sales laws. BMJ 2016; 353: i2714.

\section{Mitokondrier beskytter nerveceller etter hjerneslag}

\section{Etter et hjerneslag produserer astrocytter mitokondrier som \\ frigis og tas opp av nærliggende nevroner.}

Ved bruk av elektronmikroskopi og immunhistokjemi er det vist at astrocytter i rottehjerner skiller ut ekstracellulære mitokondrier etter et hjerneslag (1). Ved å oppregulere CD38, et enzym som deltar i reguleringen av intracellulært kalsium i astrocytter, økte mitokondrieproduksjonen i cellemediet. Indirekte stimulering av CD38 ga samme resultat.

Nevroner fra rotter ble så utsatt for oksygen- og glukosemangel. Responsen var senket intracellulært ATP-nivå og høyere dødelighet. Ved å sette til ekstracellulære mitokondrier økte både ATP-nivået og overlevelsen. I en in vivo-musemodell med påført hjerneslag ble mitokondrier i astrocytter fra primærkulturer farget og injisert i cortexområder nær infarktet tre dager etter slaget. 24 timer senere kunne man finne de transplanterte mitokondriene $\mathrm{i}$ nevroner.

- For et par år siden viste forskere at mitokondrier kan overføres mellom hjerneceller, noe man da antok var en måte å kvitte seg med dårlige mitokondrier på, sier Johanne Egge Rinholm, som er forsker ved Det medisinske fakultet, Universitetet i Oslo.

- Slik intercellulær overføring av mitokondrier er fortsatt kontroversielt, og noen forskere mener det kan være metodologiske problemer med funnene. Det nye med denne studien er at mitokondriene overføres fra astrocytter til nevroner og at mitokondriene hjelper nevronene å overleve etter slag. Hvis dette viser seg å være riktig, vil det kunne ha betydning for behandlingen av flere nevrologiske sykdommer i fremtiden. For eksempel er det påvist at mitokondriene er dysfunksjonelle ved Parkinsons sykdom og Alzheimers sykdom. Kanskje vil det bli mulig å overføre friske mitokondrier til nervecellene hos slike pasienter for å forsinke sykdomsprosessen. Men det gjenstår mye forskning før dette kan bli aktuelt, sier Rinholm.

\section{Ruth Halsne \\ Tidsskriftet \\ Litteratur \\ 1. Hayakawa K, Esposito E, Wang X et al. Transfer of mitochondria from astrocytes to neurons after stroke. Nature 2016; 535: 551-5.}

